\title{
Landslides mapped using satellite data in the Western Ghats of India after excess rainfall during August 2018
}

\author{
Tapas R. Martha*, Priyom Roy, Kirti Khanna, K. Mrinalni and \\ K. Vinod Kumar \\ Geosciences Group, National Remote Sensing Centre, Indian Space Research Organisation, Hyderabad 500 037, India
}

Excess rainfall during August 2018 triggered numerous landslides in the Western Ghats region of India covering the states of Kerala, Karnataka and Tamil Nadu. These landslides caused widespread damage to property, loss of life and adversely affected various land resources. In this article, we present an inventory of landslide prepared from the analysis of multitemporal high-resolution images acquired before and after the rainfall event from Resourcesat-2, WorldView-2, GF-2, SPOT-6 and 7, Pleiades-1, Kompsat-3 and Sentinel-2 Earth observation satellites. A total of 6970 landslides with a cumulative area of $22.6 \mathrm{sq} . \mathrm{km}$ were mapped for this rainfall event. Majority of landslides have occurred in Kerala (5191), followed by Karnataka (993) and Tamil Nadu (606). Landslides are mostly debris slide and debris flow type with entrainment along the channels. Results show that landslides $(83.2 \%)$ are triggered by very high rainfall. Also, very high rainfall has resulted in $\mathbf{1 4 . 9 \%}$ of landslides even though slopes are moderate, mainly in the Kodagu district of Karnataka.

Keywords: Debris flows, disaster response, excess rainfall, landslides, satellite data.

DURING August 2018, the Western Ghats region of peninsular India received excess rainfall due to a low pressure system in the Arabian Sea. This resulted in the worst floods in the state of Kerala during the last century and consequently triggered thousands of landslides causing death of 483 persons and large-scale loss of property ${ }^{1}$. The quantum of rainfall and inflow from the catchment were so high that crest gates of the Idukki dam on Periyar river (the largest river in Kerala) had to be opened after a span of 26 years $^{2}$. Although Kerala bore the brunt of excess rainfall, adjacent states of Karnataka and Tamil Nadu also witnessed landslides resulting in damage to plantations of cash crops such as coffee, spices, etc. ${ }^{3}$. The Bengaluru-Mangaluru railway line and hill roads were blocked at several places ${ }^{4}$. The tourism industry, which is

\footnotetext{
*For correspondence. (e-mail: tapas_martha@nrsc.gov.in)
}

the major source of income to the government and locals in all three states, was also affected due to landslides and floods.

Mapping of landslides is important to estimate the extent of damage and prioritization of rescue and relief operations. Inaccessibility of the terrain and large extent of the study area mostly drive the dependency of landslide mapping on remote sensing data. Rapid mapping of landslides and related damage using satellite data is a proven concept $\mathrm{t}^{5-9}$. Loss of vegetation and exposure of fresh rock and soil after a landslide are key criteria used in satellite-based landslide mapping ${ }^{10}$. According to Voigt et $a l .{ }^{11}$, disaster response using satellite data has shown a significant increase since the last 15 years mainly due to availability of high-resolution satellite data from international cooperation programmes such as the International Charter Space and Major Disasters (ICSMD), European Copernicus and Sentinel Asia, etc. National Remote Sensing Centre (NRSC) of the Indian Space Research Organisation (ISRO), Hyderabad is the nodal agency in India for rapid mapping and assessment of large scale landslide disaster using satellite images through its Disaster Management Support Programme $(\mathrm{DMSP})^{11}$. The recent landslide disaster in the Western Ghats was analysed using the satellite resources of ISRO with significant support from ICSMD. The value-added products on landslide distribution and damages derived from satellite data were provided as emergency response to disaster management authorities ${ }^{12,13}$.

The Western Ghats, being the second most prone area to landslide occurrences in India after the Himalaya, has always been a region of prime concern ${ }^{14,15}$. Steep slope and thick soil cover make this area susceptible to landslides ${ }^{16}$. Some of the infamous landslides that had caused large-scale deaths and damage to property in this region are Amboori landslide in Kerala, and Marapallam landslide in Tamil $\mathrm{Nadu}^{17}$. This study presents a comprehensive inventory of landslides triggered by the excess rainfall event in August 2018 in the Western Ghats region covering Kerala, Karnataka and Tamil Nadu in peninsular India, using high-resolution satellite data. 


\section{Materials and methods}

\section{Study area}

The Western Ghats (hills) runs approximately $1600 \mathrm{~km}$ parallel to the west coast of India from Gujarat to Tamil Nadu and represents a faulted escarpment, mainly made out of the Deccan plateau ${ }^{18}$. Physiographically, it can be divided into four main domains, viz. the Western Ghats, foothills, midland and coastal lowlands from east to west $^{19}$. The Western Ghats forms the major physiographic unit of the study area encompassing a length of $750 \mathrm{~km}$ from Udupi district, Karnataka in the north to Kanyakumari district, Tamil Nadu in the south. The linear trend of the Ghats is intermittently breached by the Palaghat Gap. The hill ranges of the Ghats rise to an altitude of over $2500 \mathrm{~m}$ amsl at places, occasionally forming steep slopes or escarpments. The highest point of this area is Anaimudi, which is located at an elevation of $2695 \mathrm{~m}$ amsl. The escarpment blocks the monsoon wind carrying moisture from the Arabian Sea due to orographic effect and hence causes plenty of rainfall. High rainfall makes this area a biodiversity hotspot ${ }^{20}$. The Ghats houses about 4000 plant species which represent more than $25 \%$ of the plant species in the country. The number of total endemic plant species in the Western Ghats is estimated to be 1500 (ref. $21)$. With a wide array of bioclimatic and topographic conditions, the Western Ghats has been designated as a UNESCO World Heritage Site ${ }^{22}$.

The study area is a part of the South Indian Precambrian terrain with charnockites and charnockitic gneisses forming the major and most pervasively occupying rock types. Charnockitic gneisses and pyroxene-bearing granulites occupy the major parts of the Western Ghats in Kerala, especially in the central and northern parts. Quantitatively, around $40-50 \%$ of the total area of the state comprises these rocks. The predominance of charnockites and the associated gneisses continues along the trend of the Western Ghats till the Palaghat Gap. Apart from these, rocks of the Peninsular Gneissic Complex, mainly comprising hornblende-biotite gneisses and foliated granites are seen exposed in the Palakkad and Idukki districts ${ }^{19}$.

In the southern part, beyond the Palaghat Gap, the rock types are primarily that of khondalites with garnetsillimanite-bearing gneisses. Tertiary sedimentary deposits mark the extensive coastline of the state. A total of 23 districts from the three above-mentioned states covering an area of $98,356 \mathrm{sq}$. $\mathrm{km}$ were considered for the mapping of landslides (Figure 1).

\section{Rainfall during August 2018}

Kerala received $2387 \mathrm{~mm}$ of cumulative rainfall during 1 June-21 August 2018, deviating $+41 \%$ from normal, while Karnataka and Tamil Nadu deviated $+3 \%$ and $-4 \%$ respectively, from normal rainfall ${ }^{23}$. However, rainfall distribution was not uniform both temporally and spatially. Precipitation was intense in the first and second week of August 2018. For Coimbatore and Theni districts of Tamil Nadu, and Kodagu and Dakshina Kannada districts of Karnataka, the deviation in rainfall was higher in comparison to the state average. We used daily rainfall data from Climate Prediction Center (CPC) of National Oceanic and Atmospheric Administration, USA for analysing the temporal and spatial distribution of rainfall. These data, also known as CPC Merged analysis of Precipitation (CMAP), are available for the entire globe with an approximate spatial resolution of $10 \mathrm{~km}$ (ref. 24). Figure 2 shows the daily mean rainfall in August 2018 for the most affected districts in the three states. It is observed that rainfall was high on 8 August 2018 and after a gap of two days, it resumed on 11 August and continued till 17 August with highest rainfall of the year recorded on 14 August 2018 (Figure 2). As a consequence, the area witnessed massive floods and landslides.

\section{Data}

Pre- and post-landslide high-resolution satellite data were used to map landslides (Table 1). The mapping of landslides

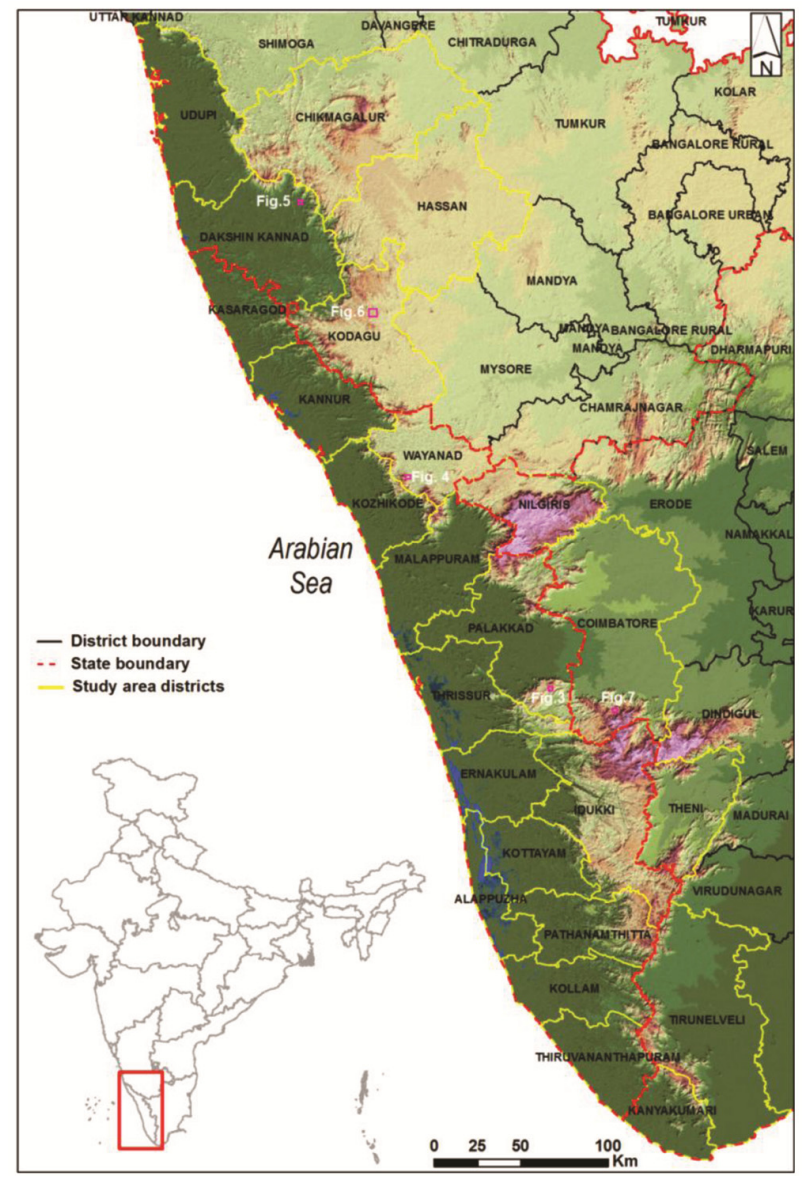

Figure 1. Painted relief map of the study area. 


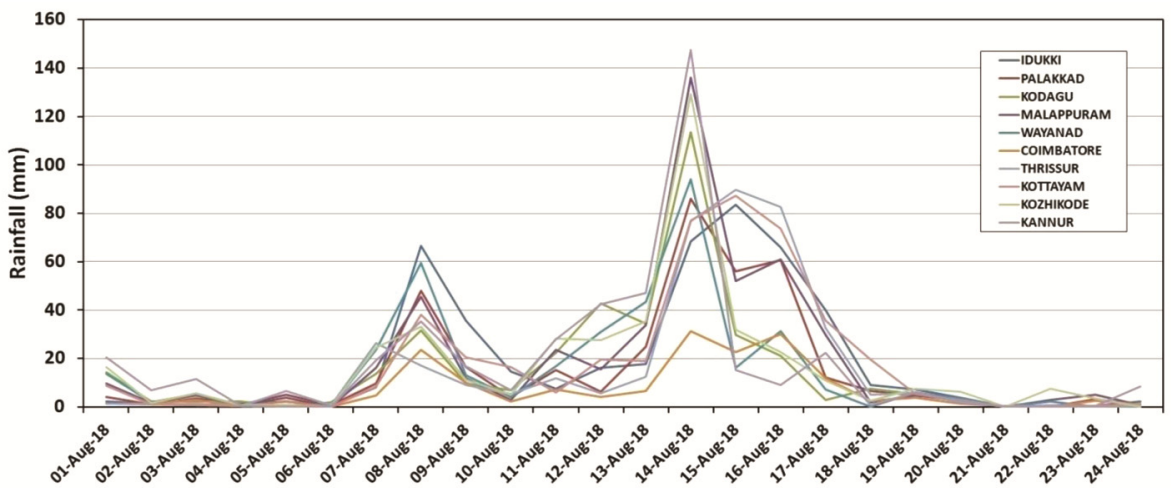

Figure 2. Graph showing daily mean rainfall (August 2018) for the most affected districts in the Western Ghats of India. Rainfall was measured from Climate Prediction Center (CPC) data.

Table 1. Satellite data used for landslide inventory mapping

\begin{tabular}{|c|c|c|c|c|}
\hline Satellite & Sensor & Resolution (m) & Date of acquisition & Source \\
\hline \multicolumn{5}{|l|}{ Pre-disaster } \\
\hline \multirow[t]{8}{*}{ Resourcesat-2,2A } & LISS-IV Mx & 5.8 & 24 January 2018 & ISRO \\
\hline & & & 22 February 2018 & \\
\hline & & & 24 February 2018 & \\
\hline & & & 1 March 2018 & \\
\hline & & & 3 March 2018 & \\
\hline & & & 8 March 2018 & \\
\hline & & & 25 March 2018 & \\
\hline & & & 30 April 2018 & \\
\hline \multirow[t]{3}{*}{ WorldView-2 } & PAN and MS & 0.46 & 12 March 2018 & USGS \\
\hline & & & 25 March 2018 & \\
\hline & & & 1 February 2018 & \\
\hline Sentinel-2 & MSI & 10 & 22 May 2018 & ESA \\
\hline \multicolumn{5}{|l|}{ Post-disaster } \\
\hline \multirow[t]{7}{*}{ Resourcesat-2A } & LISS-IV Mx & 5.8 & 4 September 2018 & ISRO \\
\hline & & & 9 September 2018 & \\
\hline & & & 16 September 2018 & \\
\hline & & & 21 September 2018 & \\
\hline & & & 28 September 2018 & \\
\hline & & & 29 October 2018 & \\
\hline & & & 27 November 2018 & \\
\hline \multirow[t]{4}{*}{ Sentinel-2 } & MSI & 10 & 6 September 2018 & ESA \\
\hline & & & 11 September 2018 & \\
\hline & & & 21 October 2018 & \\
\hline & & & 24 October 2018 & \\
\hline \multirow[t]{2}{*}{ Pleiades-1A\&1B } & PAN and MS & 0.5 & 22 August 2018 & \\
\hline & & & 25 August 2018 & CNES \\
\hline GF-2 & PMS & 3.2 & 2 September 2018 & CNSA \\
\hline Kompsat-3 & AEISS & 4 & 22 August 2018 & KARI \\
\hline \multirow[t]{2}{*}{ SPOT-6\&7 } & MI & 1.5 & 23 August 2018 & \\
\hline & & & 1 September 2018 & CNES \\
\hline WorldView-2 & PAN and MS & 0.46 & 25 August 2018 & USGS \\
\hline
\end{tabular}

for Karnataka was mainly carried out using satellite datasets such as Pleiades-1, WorldView-2, Kompsat-3, GF-2 and SPOT-6\&7 received from ICSMD. For Kerala and Tamil Nadu, landslides were mapped mainly using Resourcesat-2 and Sentinel-2 datasets. Digital elevation models (DEMs) of Shuttle Radar Topographic Mission (SRTM) $(30 \mathrm{~m})$ and CartoDEM (10 m) were also used for mapping and analysis of landslides. The study area remains under cloud during most parts of the year. Hence multiple satellite images were used to obtain a cloud-free condition of the study area. In addition to the earth observation datasets, rainfall data for the period June to August 2018, taken from CPC, were used to understand the spatial correlation of landslides with rainfall distribution. 


\section{Methodology}

Change detection analysis of satellite images acquired before and after the landslide event was performed using visual image interpretation and semi-automatic landslide detection techniques. Visual change detection for mapping of landslides was done using onscreen digitization with the help of Erdas and ArcGIS software. Semiautomatic detection of landslides was done when a large number of landslides had to be mapped from a scene. Object-based image analysis (OBIA) technique developed by Martha et al. ${ }^{10,25,26}$ was used for semi-automatic detection of landslides with eCognition software.

\section{Results and discussion}

\section{Landslide inventory}

A total of 6970 landslides were mapped in the Western Ghats covering the three states which received excess rainfall in August 2018. Table 2 shows the summary statistics of landslides. Maximum number of landslides (5191) was mapped in Kerala. Karnataka and Tamil Nadu witnessed 993 and 606 landslides respectively. Table 3 shows number of landslides mapped in each of the affected districts of the three states.

Landslides in Kerala: All the 13 hilly districts of Kerala (out of total 14 districts) were affected by landslides. Maximum number of landslides (1632) occurred in Idukki district (Table 3). High-intensity rainfall and steep slopes with highly dissected hills and valleys and thick topsoil are mainly responsible for maximum occurrence of landslides in this district. Toe cutting by rivers due to sudden release of excess water has accelerated landsliding and subsequent damage. Debris flows with long runout zones were mapped in Palakkad (Figure 3) and Wayanad districts of Kerala (Figure 4). For example, the run-out length of one such debris flow recorded in Wayanad district is $3.1 \mathrm{~km}$ (Figure 4). Figure 5 shows field photographs of landslides in Kerala.

Landslides in Karnataka: The five hilly districts of Karnataka witnessed a large number of landslides during the August 2018 event (Table 3). Ghat roads (e.g. Shiradi Ghat, Sampaje Ghat and Charmadi Ghat) connecting

Table 2. Summary statistics of landslides

\begin{tabular}{lc}
\hline Parameters & Value \\
\hline Total no. of landslides & 6970 \\
Total area (sq. km) & 22.6 \\
Minimum area $\left(\mathrm{m}^{2}\right)$ & 20.1 \\
Maximum area $\left(\mathrm{m}^{2}\right)$ & 559,000 \\
Mean area $\left(\mathrm{m}^{2}\right)$ & 3330.7 \\
\hline
\end{tabular}

Bengaluru to Mangaluru remained closed due to these landslides. The railway line connecting Bengaluru to Mangaluru was also affected at several places (Figure 6). Maximum landslides (771) were mapped in Kodagu district. The largest landslide as well as the largest total area of the landslide were identified in the district. This is mainly due to debris flows from multiple crowns coalescing in the main valley (Figure 7).

Kodagu district encompasses moderately dissected hills of the Western Ghats. The thick soil cover in the area has resulted in dominant agricultural land-use practices. Plantations and croplands (especially coffee) are predominant. The thick soil cover in the region has mostly encouraged the agricultural land-use practice and in turn has resulted in more number of landslides in the area due increase in pore water pressure after excessive rainfall.

Landslides in Tamil Nadu: The five hilly districts of Tamil Nadu adjacent to Kerala also received excess rainfall during August 2018, among which Coimbatore district witnessed maximum occurrence of landslides (Table 3). Figure 8 shows landslides (shallow and deep seated) in Tamil Nadu, similar to those in Idukki district of Kerala.

Table 3. District-wise distribution of landslides in the three affected states

\begin{tabular}{|c|c|c|}
\hline Districts & No. of landslides & Area of landslides $\left(\mathrm{m}^{2}\right)$ \\
\hline \multicolumn{3}{|l|}{ Kerala } \\
\hline Kasaragod & 81 & 87,009 \\
\hline Kannur & 145 & 377,528 \\
\hline Wayanad & 474 & $1,224,631$ \\
\hline Kozhikode & 152 & 617,132 \\
\hline Malappuram & 511 & $1,343,347$ \\
\hline Palakkad & 1298 & $3,220,440$ \\
\hline Thrissur & 387 & $1,732,639$ \\
\hline Ernakulam & 80 & 386,173 \\
\hline Idukki & 1632 & $3,962,401$ \\
\hline Kottayam & 170 & 284,984 \\
\hline Pathanamthitta & 161 & 342,989 \\
\hline Kollam & 27 & 55,017 \\
\hline Thiruvananthapuram & 73 & 140,204 \\
\hline Total & 5191 & $13,774,492$ \\
\hline \multicolumn{3}{|l|}{ Karnataka } \\
\hline Kodagu & 771 & $7,106,865$ \\
\hline Dakshina Kannada & 88 & 156,869 \\
\hline Chikkamagaluru & 34 & 71,735 \\
\hline Hassan & 74 & 399,456 \\
\hline Udupi & 26 & 64,414 \\
\hline Total & 993 & $7,799,339$ \\
\hline \multicolumn{3}{|l|}{ Tamil Nadu } \\
\hline Nilgiris & 28 & 26,551 \\
\hline Coimbatore & 447 & 793,250 \\
\hline Theni & 42 & 82,073 \\
\hline Tirunelveli & 59 & 93,965 \\
\hline Kanyakumari & 30 & 45,227 \\
\hline Total & 606 & $1,041,066$ \\
\hline Gross Total & 6970 & $22,615,845$ \\
\hline
\end{tabular}



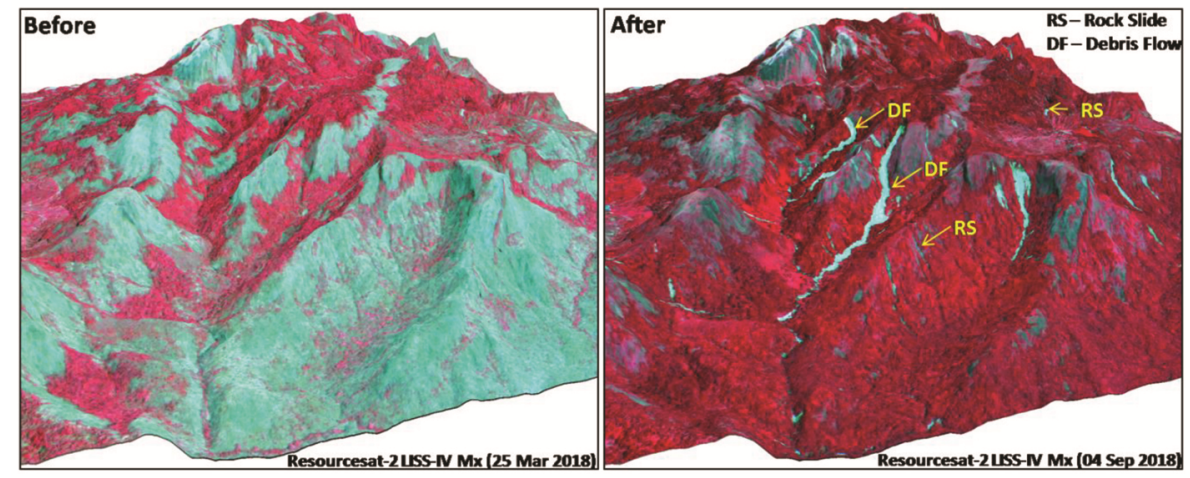

Figure 3. Three-dimensional perspective view of debris flow and rock slide triggered by the August 2018 rainfall event in Palakkad district, Kerala.

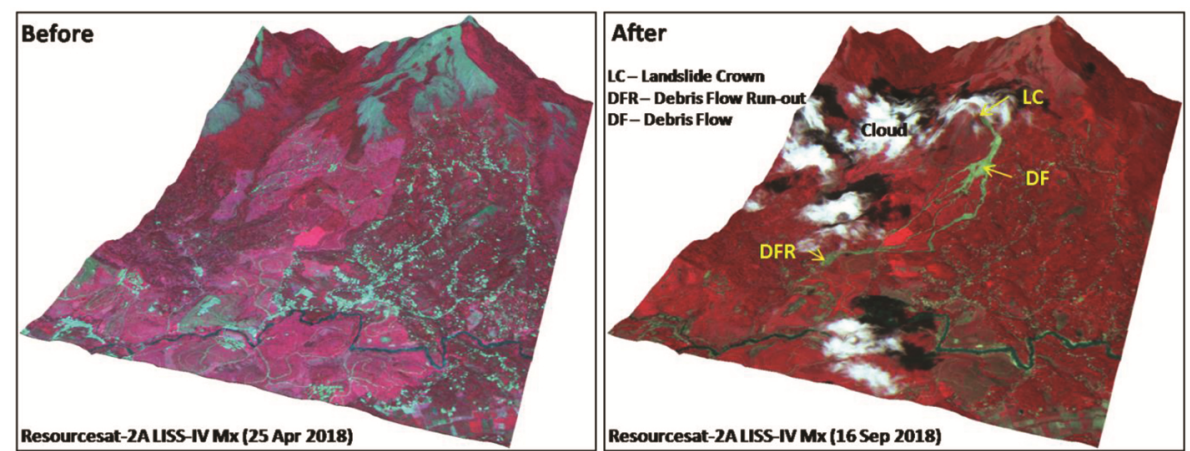

Figure 4. Three-dimensional perspective view of multichannel debris flow triggered by the August 2018 rainfall event in Wayanad district, Kerala.

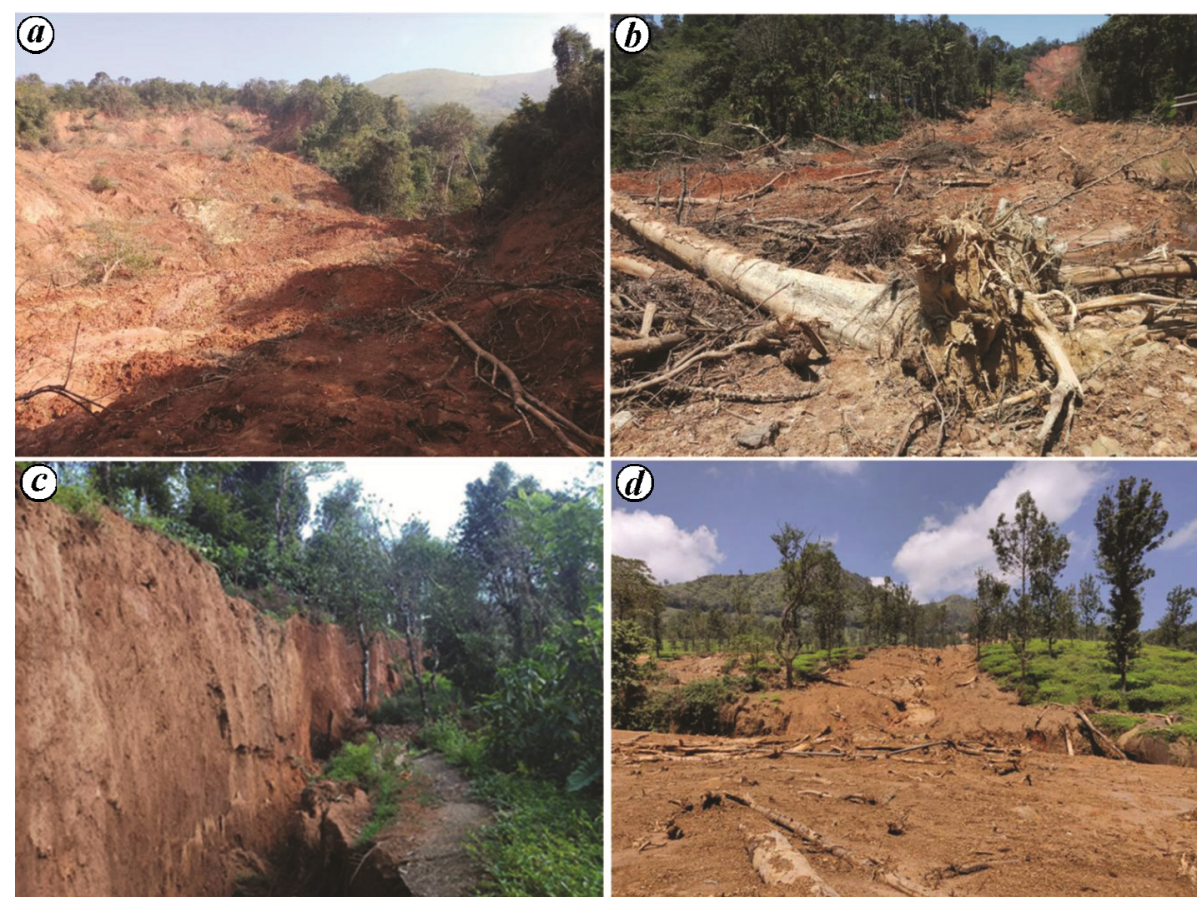

Figure 5. Field phogographs of landslides in Kerala. (a, b) Debris flow near Pilakavu (a), Pancharakolli (b). (c) Crown and tension cracks of rotational landslide near Plamoola. (d) Debris flow within a plantation near Kurichelmala (courtesy: Vincent Ferrer, National Centre for Earth Science Studies, Thiruvananthapuram). 


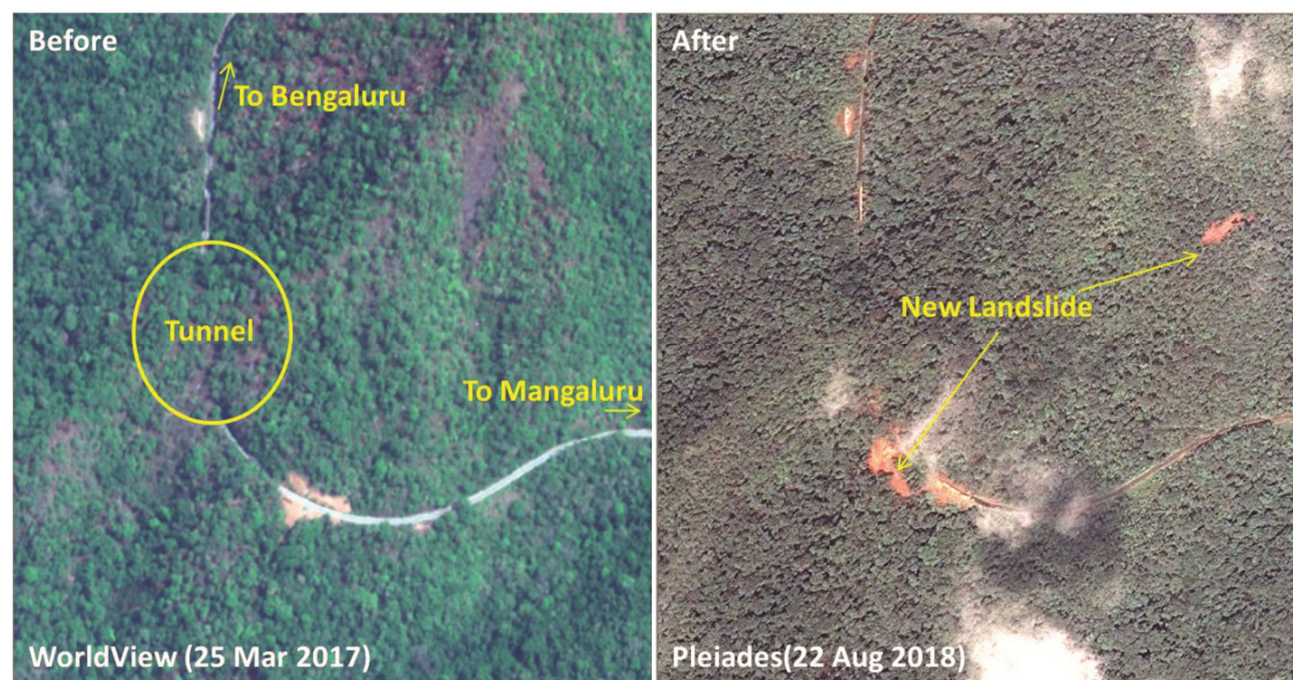

Figure 6. Blockage of Bengaluru-Mangaluru railway line due to landslide near a tunnel in Dakshina Kannada district, Karnataka.

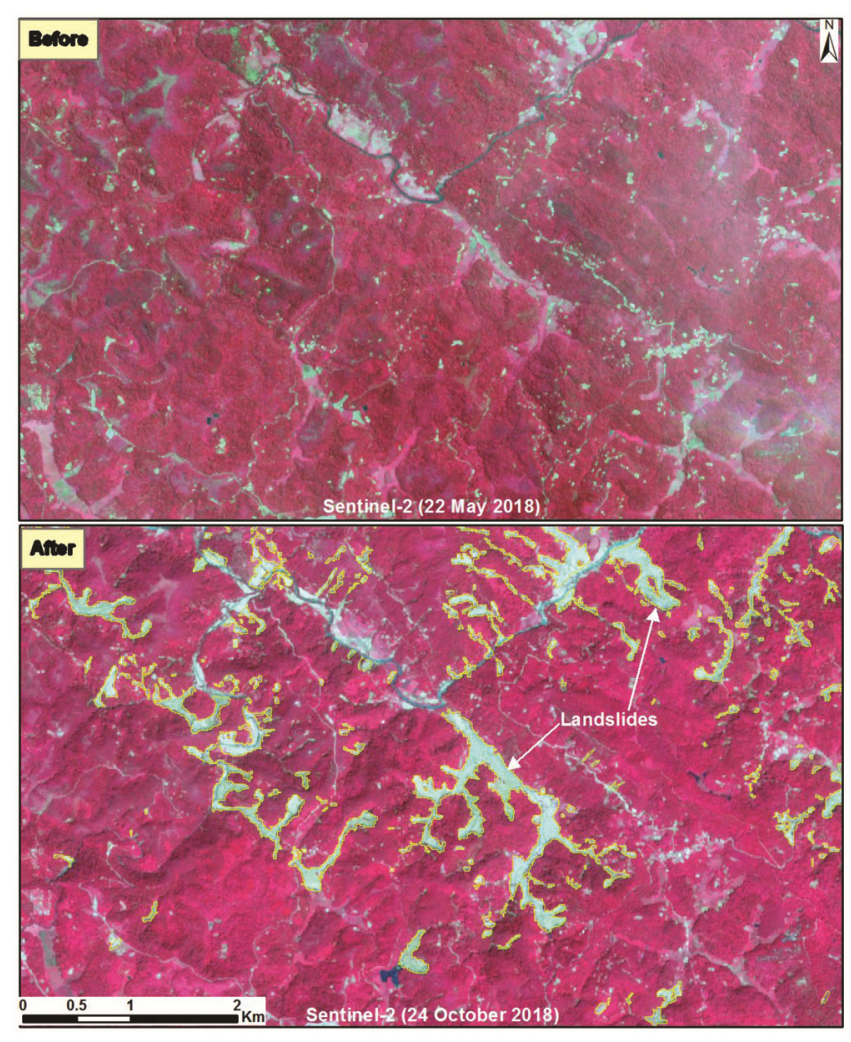

Figure 7. Landslides triggered by the August 2018 rainfall event in Kodagu district, Karnataka.

The landslides in Coimbatore are mostly concentrated towards the south of the district. Regionally, the most pervasive land-use practice in the area is croplands with coffee/tea plantations along the hill slope. Along with the high dissection of the hill slopes, the agricultural pattern may have loosened the topsoil resulting in more landslides being triggered in the area.

\section{Relationship of landslide distribution to slope and rainfall}

Significant deviation of rainfall from the normal was found in Idukki, Wayanad, Palakkad and Kodagu among all the 23 districts (Figure 9). Maximum rainfall during the August 2018 event was recorded in Idukki district. In Tamil Nadu, only the districts adjacent to Kerala (Coimbatore $(+403 \%)$, Kanyakumari $(+52 \%)$, Nilgiri $(+21 \%)$, Theni $(+350 \%)$ and Tirunelveli $(+188 \%))$ received excess to large excess rainfall. Similarly, in Karnataka, Kodagu, Chikkmagalur and Dakshina Kannada districts received excess to large excess rainfall.

As shown in Figure 9, occurrence of landslides depicted a good correlation with rainfall deviation. For example, Idukki and Palakkad had the highest deviation of rainfall, and also the highest number of landslides in Kerala. It is also evident from Figure 9 that Kollam and Thiruvananthapuram districts witnessed relatively less number of landslides, though rainfall deviation was more. This can be attributed to less amount of total rainfall in comparison to other districts such as Idukki and Palak$\mathrm{kad}$, and exposure of landslide-prone areas mainly in the eastern parts of the districts. Similarly, rainfall deviation is relatively less in Wayanad and Thrissur districts, while the occurrence of landslides is high due to high cumulative rainfall and steep slope (Figure 9).

Figure 10 shows the spatial distribution of landslides and cumulative rainfall in August 2018. It clearly indicates that majority of landslides are triggered by excess rainfall. In order to study the role of rainfall and slope on the occurrence of landslides, we classified the cumulative rainfall and slope into five classes based on natural breaks method. The analysis shows that the occurrence of landslides $(83.2 \%)$ is significantly controlled by very high rainfall. Also, very high rainfall has resulted in $14.9 \%$ of 

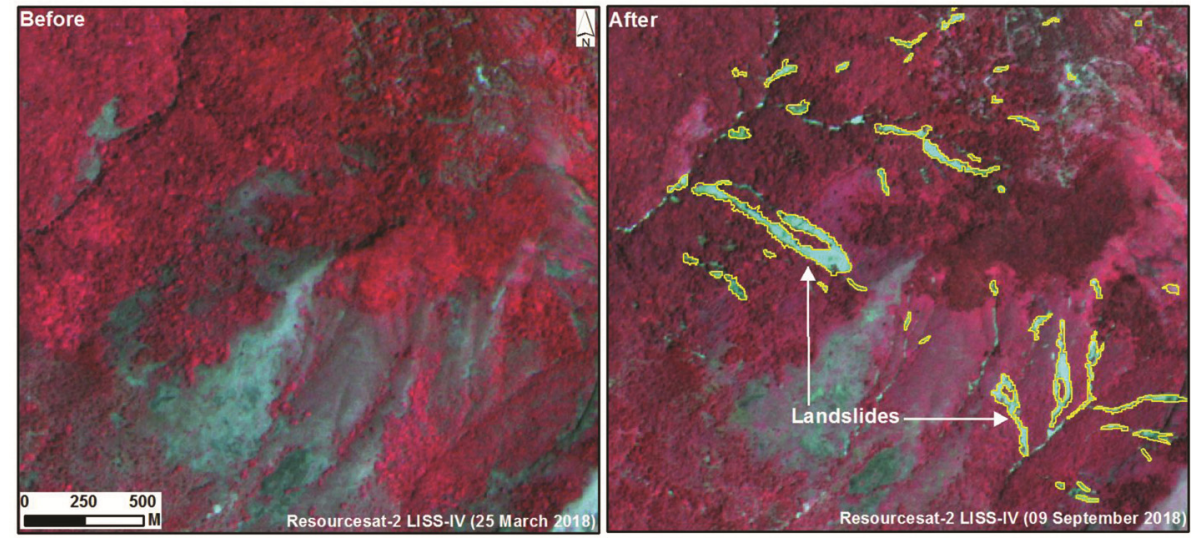

Figure 8. Landslides triggered by the August 2018 rainfall event in Coimbatore district, Tamil Nadu.

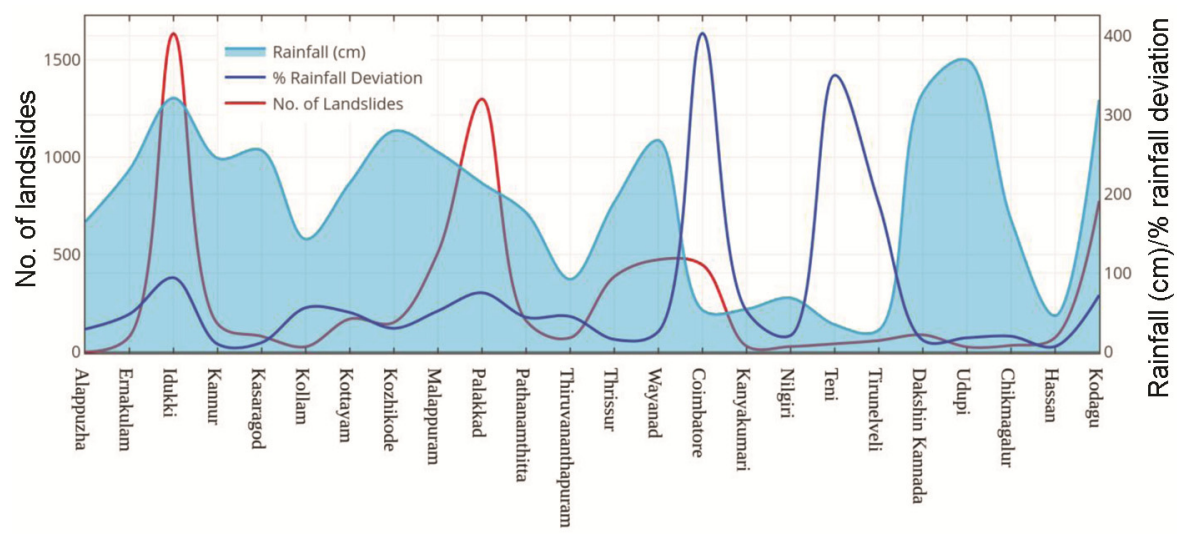

Figure 9. Graph showing total rainfall and \% rainfall deviation from normal for 23 districts in three states during 1 June-21 August 2018 (data source: IMD). Total number of landslides mapped in each district is also shown.

Table 4. Landslide percentage in slope and rainfall classes

\begin{tabular}{llrlrrrr}
\hline & \multicolumn{7}{c}{ Rainfall } \\
\cline { 3 - 7 } & & Very low & Low & Moderate & High & Very high & Total \\
\hline \multirow{2}{*}{ Slope } & Very low & 0.00 & 0.04 & 0.03 & 0.19 & 0.84 & 1.10 \\
& Low & 0.00 & 0.07 & 0.34 & 1.40 & 5.79 & 7.60 \\
& Moderate & 0.00 & 0.15 & 0.43 & 2.25 & 14.90 & 17.73 \\
& High & 0.00 & 0.16 & 0.41 & 4.76 & 30.34 & 35.67 \\
& Very high & 0.00 & 0.13 & 0.32 & 6.13 & 31.31 & 37.89 \\
& Total & 0.00 & 0.56 & 1.53 & 14.73 & 83.18 & 100 \\
\hline
\end{tabular}

Class intervals are shown in Figure 9.

landslides even though slopes are moderate, mainly in Kodagu district, Karnataka. Very high and high slopes contribute almost equally to the occurrence of landslides (Table 4).

\section{Conclusion}

The Western Ghat region of the South Indian peninsula received excess rainfall, particularly during August 2018.
High-intensity rainfall was recorded on 8 August 2018, followed by another spell of excess rainfall during 11-17 August 2018. The first spell of rainfall would have saturated the pore spaces of the soil with consequent landslides during the second spell of excess rainfall. Idukki district in Kerala witnessed maximum rainfall during this event, resulting in the highest occurrence of landslides among all neighbouring districts. Most of the landslides are debris slides and debris flows confined to 

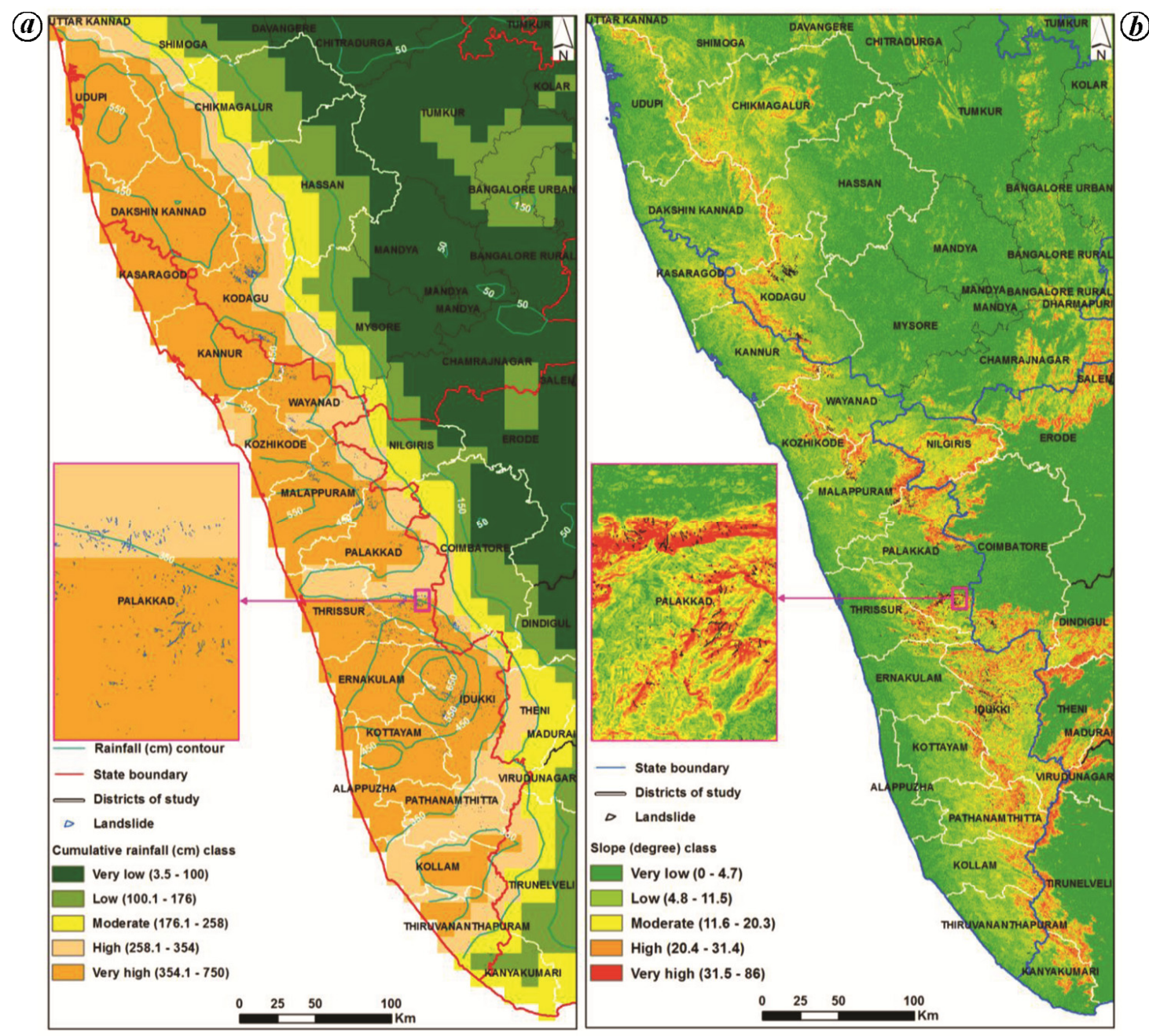

Figure 10. $\boldsymbol{a}$, Spatial distribution landslides and cumulative rainfall in August 2018. $\boldsymbol{b}$, Spatial distribution of landslides with respect to slope angle.

channels with long run-outs. Several shallow translational landslides have also been mapped in these areas. Kodagu district witnessed maximum occurrence of landslides in Karnataka. Landslides in this district are mainly debris flow type and occurred on moderate slope area due to saturation of soil. A large number of landslides were also mapped in Coimbatore district of Tamil Nadu. Although highest number landslides was mapped in Idukki district, the total area of landslide was maximum in Kodagu district due to debris flows with multiple crowns coalescing into the valley. We have mapped all landslides in these three states using high-resolution satellite data; however, small landslides within urban areas or below the dense canopy without damage of the forest strand might have been overlooked during the mapping.

1. https://indianexpress.com/article/india/483-dead-in-kerala-floods-andlandslides-losses-more-than-annual-plan-outlay-pinarayi-vijayan5332306/ (accessed on 3 June 2019).

2. https://www.indiatoday.in/india/story/kerala-rains-all-5-gates-idukkidam-open-1310804-2018-08-10 (accessed on 3 June 2019).
3. https://www.indiatoday.in/india/story/tamil-nadu-heavy-rain-triggersflood-landslides-in-attakatti-1316906-2018-08-17 (accessed on 3 June 2019).

4. https://timesofindia.indiatimes.com/city/bengaluru/landslides-onghats-how-to-connect-bengaluru-mangaluru-and-udupi/ articleshow/65505135.cms (accessed on 3 June 2019).

5. Martha, T. R., Roy, P., Mazumdar, R., Babu Govindharaj, K. and Vinod Kumar, K., Spatial characteristics of landslides triggered by the $2015 M_{\mathrm{w}} 7.8$ (Gorkha) and $M_{\mathrm{w}} 7.3$ (Dolakha) earthquakes in Nepal. Landslides, 2017, 14, 697-704.

6. Martha, T. R., Roy, P. and Vinod Kumar, K., Rapid assessment of the valley blocking 'So Bhir' landslide near Mantam village, North Sikkim using satellite image. Curr. Sci., 2017, 113, 1228-1229.

7. Metternicht, G., Hurni, L. and Gogu, R., Remote sensing of landslides: an analysis of the potential contribution to geo-spatial systems for hazard assessment in mountainous environments. Remote Sensing Environ., 2005, 98, 284-303.

8. van Westen, C. J. and Lulie Getahun, F., Analyzing the evolution of the Tessina landslide using aerial photographs and digital elevation models. Geomorphology, 2003, 54, 77-89.

9. Voigt, S., Kemper, T., Riedlinger, T., Kiefl, R., Scholte, K. and Mehl, H., Satellite image analysis for disaster and crisismanagement support. IEEE Trans. Geosci. Remote Sensing, 2007, 45, 1520-1528. 
10. Martha, T. R., Kerle, N., Jetten, V., van Westen, C. J. and Vinod Kumar, K., Characterizing spectral, spatial and morphometric properties of landslides for automatic detection using objectoriented methods. Geomorphology, 2010, 116, 24-36.

11. Voigt, S. et al., Global trends in satellite-based emergency mapping. Science, 2016, 353, 247-252.

12. www.bhuvan-noeda.nrsc.gov.in/disaster/disaster/disaster.php?id= landslide monitor (accessed on 21 January 2019).

13. https://disastercharter.org/web/guest/activations/-/article/landslide-inindia-activation-584 (accessed on 21 January 2019).

14. Thampi, P. K., Mathai, J. and Sankar, G., Landslides (urul pottal) in Western Ghats: some field observations. In Proceedings of the Seventh Kerala Science Congress, Palakkad, January 1995, pp. 97-99.

15. Kuriakose, S. L., Sankar, G. and Muraleedharan, C., History of landslide susceptibility and a chorology of landslide-prone areas in the Western Ghats of Kerala, India. Environ. Geol., 2009, 57(7), 1553-1568.

16. Sajinkumar, K. S., Anbazhagan, S., Pradeepkumar, A. P. and Rani, V. R., Weathering and landslide occurrences in parts of Western Ghats, Kerala, India. J. Geol. Soc. India, 2011, 78, 249-257.

17. Jaiswal, P., van Westen, C. J. and Jetten, V., Quantitative assessment of landslide hazard along transportation lines using historical records. Landslides, 2011, 8, 279-291.

18. Radhakrishna, B. P., Geomorphic rejuvenation of the Indian Peninsula. In Sahyadri: The Great Escarpment of the Indian Subcontinent (eds Gunnel, Y. and Radhakrishna, B. P.), Geological Society of India, Bengaluru, 2001, pp. 201-211.

19. Soman, K., Geology of Kerala, Geological Society of India, Bengaluru, 2002, p. 335.

20. Myers, N., Threatened biotas: 'hotspots' in tropical forests. Environmentalist, 1988, 8, 1-20.

21. Ramesh, B. R., Patterns of vegetation, biodiversity and endemism, in Western Ghats. Mem. Geol. Soc. India, 2001, 47, 973-981.
22. https://whc.unesco.org/en/list/1342 (accessed on 21 January 2019).

23. www.hydro.imd.gov.in/hydrometweb (accessed on 21 January 2019).

24. www.cpc.ncep.noaa.gov (accessed on 21 January 2019).

25. Martha, T. R., Kamala, P., Josna, J., Vinod Kumar, K. and Jai Sankar, G., Identification of new landslides from high resolution satellite data covering a large area using object-based change detection methods. J. Indian Soc. Remote Sensing, 2016, 44, 515524.

26. Martha, T. R., Kerle, N., van Westen, C. J., Jetten, V. and Vinod Kumar, K., Segment optimisation and data-driven thresholding for knowledge-based landslide detection by object-based image analysis. IEEE Trans. Geosci. Remote Sensing, 2011, 49, 4928-4943; doi:10.1109/TGRS.2011.2151866.

ACKNOWLEDGEMENTS. This article is the outcome of the disaster support work carried out under the Decision Support Centre (DSC) activities of National Remote Sensing Centre (NRSC), Hyderabad supervised by Santanu Chowdhury (Director, NRSC) and Dr P. V. N. Rao (NRSC). T.R.M. was the Project Manager of International Charter Space and Major Disasters (ICSMD) for the landslide event in Karnataka, and thanks ICMSD and its affiliated organizations for sharing satellite images in a timely manner for the generation of value-added products. We thank Dr Vincent A Ferrer (NCESS, Thiruvananthapuram) for sharing field photographs of Kerala landslides. We also thank Dr P. G. Diwakar, Dr G. Srinivasa Rao and Dr K. H. V. Durga Rao for support during our response to the Kerala disaster in August 2018.

Received 23 January 2019; revised accepted 6 June 2019

doi: $10.18520 / \mathrm{cs} / \mathrm{v} 117 / \mathrm{i} 5 / 804-812$ 